\title{
Morphological diversity of xoconostles (Opuntia spp.) or acidic cactus pears: a Mexican contribution to functional foods
}

\author{
Clemente Gallegos-Vázquez ${ }^{1}$, Leia ScheinvaR ${ }^{2}$, Carlos A. NúÑEZ-Colín ${ }^{3}$, Candelario MondRagón-JaCobo ${ }^{3 *}$
}

${ }^{1}$ Cent. Reg. Univ. Centro Norte, Univ. Auton. Chapingo, Apartado Post. 196,

Zacatecas, 98001, Zacatecas, Mexico,

red_nopal_rfaa@yahoo.com.mx

2 Jard. Bot., Inst. Biol., Univ. Nac. Auton. México, Ciudad Univ., México D.F., 0451, México

${ }^{3}$ Campo Exp. Bajío, Inst. Nac. Investig. For. Agríc. Pecu., Apartado Post. 112, Celaya, 38110, Guanajuato, Mexico, jacobo77@hotmail.com

${ }^{*}$ Correspondence and reprints

Received 18 November 2010 Accepted 15 February 2011

Fruits, 2012, vol. 67, p. 109-120 (C) 2012 Cirad/EDP Sciences All rights reserved DOI: $10.1051 /$ fruits/2012001 www.fruits-journal.org

RESUMEN ESPAÑOL, p. 120

\section{Morphological diversity of xoconostles (Opuntia spp.) or acidic cactus pears: a} Mexican contribution to functional foods.

Abstract - Introduction. Xoconostles or acidic cactus pears (Opuntia spp.) are fruits prized for their fleshy and acidic mesocarp; they are morphologically different from cactus pears which are sweet, juicy and seedy. Both thrive in semiarid highlands of Central Mexico, tolerate poor soils and scanty rainfall, and have evolved into formal crops during the last five decades. Wild xoconostles are ubiquitous in Mexican semiarid regions. Domesticated genotypes are found in backyards and commercial orchards. Folk wisdom attributes xoconostle with antihypoglycemic effects, cholesterol control and obesity reduction. The peel presents higher antioxidant capacity than strawberry, raspberry, red plum, grapefruit, pear and apple. Our investigation describes the main cultivars of xoconostles with horticultural value for human consumption in Central Mexico; it contributes to the elucidation of their morphological relationships. Materials and methods. Twenty-one accessions from the Hidalgo and Zacatecas states of Mexico were described using 27 variables from cladodes, flowers and fruits; significant variables were selected by correlation and PCA, and thereafter a cluster analysis and discriminant canonical analysis were performed. Results. Thirteen variables were found to be significant to discriminate accessions: cladode length, number of rows of areoles, number of areoles in the central row, pericarp length and width, fruit length, fruit diameter, [length / diameter] ratio, areole density, receptacle depth, fruit and peel weight, and pulp acidity. Two canonical roots (Can) explained variability: Can1 (fruit areola density, acidity, number of areole rows, and number of areoles in the central row) explained $87.55 \%$, and Can2 (peel weight, fruit weight and fruit diameter) explained the remaining $12.45 \%$. Discussion. Can1 was related to plant productivity, while Can2 comprised mainly fruit quality traits. Both of these traits are of primary interest for human utilization and have had a clear effect on domestication. Clusters did not match the actual taxonomic classification.

Mexico / Opuntia / genetic resources / biodiversity / human feeding

Diversité morphologique des xoconostles (Opuntia spp.) ou figues de Barbarie acides : une contribution mexicaine à l'alimentation de base.

Résumé - Introduction. Les xoconostles ou figuiers de Barbarie acides (Opuntia spp.) ont des fruits charnus, appréciés pour leur mésocarpe acide ; ils sont morphologiquement différents des figues de Barbarie qui sont douces, juteuses et remplies de graines. Les deux espèces se développent sur les plateaux semi-arides du Mexique central ; ils tolèrent des sols pauvres et des pluies peu abondantes ; leur culture a évolué régulièrement au cours des cinq dernières décennies. Les xoconostles sauvages sont omniprésents dans les régions semi-arides du Mexique. Des génotypes domestiqués sont trouvés dans les jardins de case et les vergers commerciaux. La sagesse populaire attribue aux xoconostles des vertus antihypoglucémiques, de contrôle du cholestérol et de réduction de l'obésité. La peau a des propriétés antioxydantes supérieures à celles des fraises, framboises, prunes rouges, pamplemousses, poires et pommes. Notre enquête décrit les principaux cultivars horticoles de xoconostles présentant un intérêt pour la consommation humaine dans le Mexique central ; elle contribue à l'élucidation de leurs parentés morphologiques. Matériel et méthodes. Vingt et une accessions collectées dans les États d'Hidalgo et de Zacatecas au Mexique ont été décrits en utilisant 27 variables de cladodes, fleurs et fruits ; les variables significatives ont été sélectionnées par des études de corrélation et par une analyse en composantes principales, puis par une analyse typologique et une analyse canonique discriminante. Résultats. Treize variables ont été jugées importantes pour discriminer les accessions : longueur de cladode, nombre de rangs d'aréoles, nombre d'aréoles dans le rang central, longueur et largeur du péricarpe, longueur du fruit, diamètre des fruits, rapport [longueur du fruit / diamètre du fruit], densité des aréoles, profondeur du réceptacle, poids des fruits, poids de la peau et acidité de la pulpe. Deux variables canoniques (Can) ont expliqué la variabilité : Can 1 (densité d'aréole dans le fruit, acidité, nombre de rangs d'aréoles, nombre d'aréoles dans le rang central) a expliqué $87,55 \%$ de la variabilité, et Can 2 (poids de peau, poids des fruits et diamètre des fruits) a expliqué les $12,45 \%$ restants. Discussion. La variable Can 1 serait liée à la productivité des plantes, tandis que la variable Can 2 regrouperait principalement les caractéristiques de qualité des fruits. L'ensemble de ces caractères sont d'un intérêt primordial pour l'utilisation humaine et ont eu un effet manifeste sur la domestication. Les groupes d'accessions mis en évidence ne correspondent pas à la classification taxonomique réelle.

Mexique / Opuntia / ressource génétique / biodiversité / alimentation humaine 
Figure 1.

External and internal features of xoconostle and cactus pear fruits: the edible part of the xoconostle is the thick mesocarp, the seed core is discarded. Cactus pears, on the other hand, present an enlarged funiculus originating on the external tissue of the seed; it is sweet with grainy, paste-like, or juicy texture depending upon the cultivar.

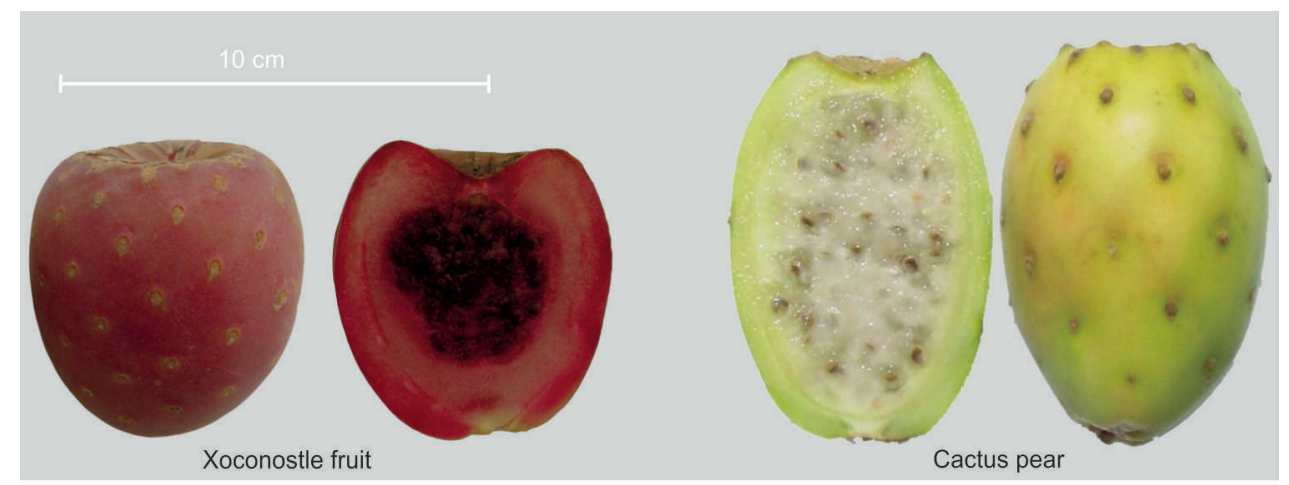

\section{Introduction}

Xoconostles or acidic cactus pears (Opuntia sp.) as described by their Aztec name $($ xoco $=$ acid, noxtle $=$ pear-like $)$ are produced by a specific cactus pear plant bearing fruits prized for their fleshy, acidic mesocarp. They are morphologically different from their cousins the cactus pears which are recognized by their sweet, juicy and seedy endocarp (figure 1). Both plants thrive under the semiarid conditions of the highlands of Central Mexico; they are tolerant to poor stony soils and scanty rainfall, and have evolved into formal crops during the last five decades [1].

Wild xoconostles are a common feature of the Mexican landscape of semiarid regions. They can be found in open areas of Central Mexico growing beside xerophytes such as mesquites (Prosopis laevigata), huizaches (Prosopis juliflora) and prickly pears (Opuntia streptacantha). As the climate and soil become limiting towards north Central Mexico, they share the territory with "garambullos" (Myrtillocactus geometrizans), "chollas" (Cylindropuntia cholla), biznagas (Echinocactus spp.) and yuccas (Yucca spp.). Semi-domesticated genotypes can be found in family orchards of both regions. The wild areas act as natural open reservoirs for fruit gathering by farmers and ranchers. During the last two decades the interest in xoconostles has increased due to their nutritional and functional properties.

There are several species bearing edible xoconostle fruits; nine were reported by Olivares-Orozco et al. [2], while Scheinvar et al. [3] described nine Opuntia and one Cylindropuntia species (O. heliabravoana Scheinvar, O. elizondoana E. Sánchez \& Villaseñor, O. joconostle F.A.C. Weber, O. matudae Scheinvar, O. spinulifera Salm-Dyck, O. leucotricha DC, O. zamudioi Scheinvar, O. durangensis Britton \& Rose, O. oligacantha C.F. Förster and Cylindropuntia imbricata DC). The Opuntia bearing xoconostle fruits are recognized by their edible, thick mesocarp and hard-coated seeds loosely packed in the central part of the fruit, which is scooped out before consumption. After ripening they can remain attached to the pad or cladode for almost a year: this is certainly a valuable agronomic feature. Ávalos-Andrade et al. reported that this feature is probably associated with the low rate of ethylene released during ripening [4].

Besides xoconostles there are other cacti bearing pear-like fruits which are probably natural hybrids of cactus pears and xoconostles. They are recognized by the popular name of "xocotunas" and belong to the following species: O. chavena Griffths, O. lasiacantha Pfeiff., O. megacantha Salm-Dick, $O$. streptacantha Lem. and O. robusta Wendl. In general, their fruits are small, with a thick, spongy, mesocarp and seeds packed in a central core. In comparison, "xocotunas" bear a fruit type similar to xoconostles but with semi-acid or slightly sweet pulp [5].

Xoconostles have hermaphrodite flowers and they may present xenogamy and autogamy depending upon the species. While wasps are the main pollinators, bees, small beetles and even birds contribute to pollination. However, the apparent specialization of bees pollinating Opuntia contributes to their natural hybridization [6]. 
The xoconostles have been an important plant resource for traditional farmers who routinely utilize the fruits in their daily diet. The most common recipe is to slice and mix them with tomatoes, onions and hot peppers. Adding diced xoconostle to salsas gives them a special zesty acidic flavor. They can also be used as a base for refreshing drinks.

Whole fruits can be caramelized or dehydrated. The juice can be made into liquors. They are also recognized as an alternative medicine due to their antihypoglycemic effects, high cholesterol control and body weight reduction $[2,7]$.

Guzmán-Maldonado et al. reported xoconostle peel is an outstanding source of fiber, minerals, simple soluble phenolics and betalains [8]. A 100-g portion of peel and skin could contribute up to $58 \%$ and $13 \%$ of daily iron and zinc requirements, respectively. The peel and skin show considerably higher Trolox equivalent antioxidant capacity (TEAC) (13-16 mmol Trolox equivalent (TE) $100 \mathrm{~g}^{-1} \mathrm{FWB}$ ) than strawberry, raspberry, red plum, grapefruit, orange, pear and apple [(2.59, 1.85, 1.83, 0.86, 0.85, 0.28 and $\left.0.34) \mathrm{mmol} \mathrm{TE} \cdot 100 \mathrm{~g}^{-1} \mathrm{FWB}\right]$, respectively [9]. Pimienta-Barrios et al. reported the effects of ingestion of fresh xoconostle on diabetes type II [10]. They observed a significant increase in the insulin levels and a human growth hormone (hGH).

Due to its commercial potential, xoconostle cultivation is catching the attention of growers. Unofficial statistics report that there are around 600 ha comprising formal orchards as well as mixed cactus pear/ xoconostle plantations. The extent of the wild areas covered by Opuntia - including xoconostle - in Central Mexico is unknown [5]. Human development is taking its toll on wild stocks of Opuntia. Animal grazing, land clearing for cereal cultivation, and the destruction of entire cactus pear stocks for forage, especially during drought spells, are the threats to Opuntia diversity in Central Mexico [11, 12]. Therefore, collection and documentation are key steps to promote its conservation.

According to Gallegos-Vázquez et al., a comparative study carried out with acces- sions obtained from Central Mexico demonstrated clear morphological differences between the xoconostles and cactus pears [13]. For horticultural use, the absence of pulp and the presence of an edible thick pericarp are the most significant differences. Xoconostles also presented more flowers per cladode, shorter fruit length and diameter, higher density of areolas on the fruit, pulp weight, [peel weight / fruit weight] ratio, and total soluble solids.

In general, characterization of xoconostles is incomplete. There are a few descriptions using either vegetative or reproductive traits. They usually lack botanical references and other data, which makes it difficult to properly document [3] and limit their application in formal proposals of rescue, conservation and sustainable utilization.

The objective of our investigation was to describe the main cultivars of xoconostles with horticultural value for human consumption present in Central Mexico, and to contribute to the elucidation of their morphological relationships based on 27 traits collected from cladodes, flowers and fruits following the International Union for the Protection of New Varieties of Plants (UPOV) guidelines [14]. In the future this data may be used for the purpose of registration.

\section{Materials and methods}

Samples of twenty-one accessions were collected at two locations (table I, figure 2). The community collection of native Opuntia species procured by Mr. Fidel Orozco-Aguilar located in Villa de Tezontepec, Hidalgo, and wild stocks of Saín Alto, Zacatecas, Mexico, together contain the most important cultivars for the fresh fruit trade and agroindustrial applications. The outstanding accessions may be readily incorporated into cultivation (table II, figure 3).

Twenty-seven variables from cladodes, flowers and fruits were measured. Cladode variables included: length, width, thickness, number of rows of areoles, number of areolas in the central row, number of spines in the central areole, and length of the central 


\section{Table I.}

Main features of two collection sites in Mexico, where xoconostle accessions were selected to study morphological diversity of Opuntia spp.

\begin{tabular}{|c|c|c|c|c|c|c|c|c|c|}
\hline Feature & Latitude & Longitude & $\begin{array}{l}\text { Altitude } \\
\text { (m) }\end{array}$ & $\begin{array}{c}\text { Mean annual } \\
\text { temperature } \\
\left({ }^{\circ} \mathrm{C}\right)\end{array}$ & $\begin{array}{c}\text { Annual } \\
\text { rainfall } \\
(\mathrm{mm})\end{array}$ & Soil type & Climate & Land use & Vegetation \\
\hline $\begin{array}{l}\text { Villa de } \\
\text { Tezontepec, } \\
\text { Hidalgo }\end{array}$ & $19^{\circ} 53^{\prime} 00^{\prime \prime}$ & $98^{\circ} 49^{\prime} 00^{\prime \prime}$ & 2320 & 14.5 & 508 & Phaeozem & $\begin{array}{c}\text { Temperate } \\
\text { semiarid with } \\
\text { summer rainfall }\end{array}$ & $\begin{array}{l}\text { Agricultural } \\
\text { rainfed }\end{array}$ & $\begin{array}{l}\text { Maize, barley, } \\
\text { cactus pear }\end{array}$ \\
\hline $\begin{array}{l}\text { Saín Alto, } \\
\text { Zacatecas }\end{array}$ & $23^{\circ} 34^{\prime} 46^{\prime \prime}$ & $103^{\circ} 14^{\prime} 49^{\prime \prime}$ & 2050 & 16.0 & 500 & $\begin{array}{c}\text { Phaeozem / } \\
\text { leptosol }\end{array}$ & $\begin{array}{c}\text { Temperate } \\
\text { semiarid with } \\
\text { summer rainfall }\end{array}$ & $\begin{array}{l}\text { Grassland } \\
\text { cattle } \\
\text { fattening }\end{array}$ & $\begin{array}{l}\text { Xerophytic, } \\
\text { grasses }\end{array}$ \\
\hline
\end{tabular}

\section{Figure 2.}

Geographical location of areas where Opuntia spp. were collected; both areas are located in the semiarid highlands, characterized by a semiarid climate and poor soils.

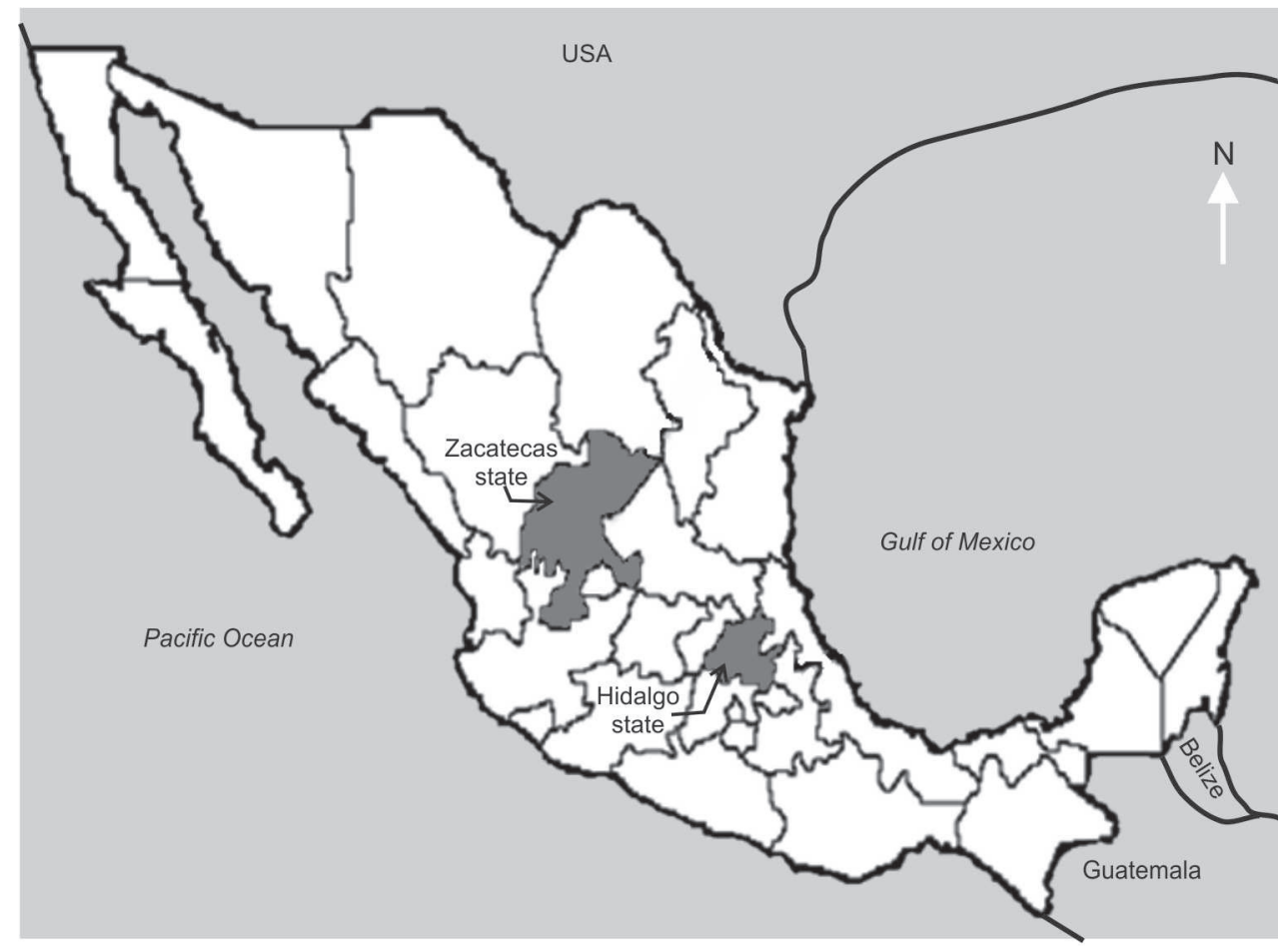

spine. Flower variables consisted of: total length including corolla, pericarpel length and width, and number of lobes of the stigma. We used 20 flowers for studying these variables. Fruit variables were: length, diameter, [length / diameter] ratio, areola density, peduncle length (section of the bottom of the fruit devoid of pulp), receptacle depth, diameter, peel thickness, total weight, peel weight, pulp weight, [pulp / peel] ratio, number of fully developed and aborted seeds, total soluble solids, and acidity. Eight to twelve plants per accession were sampled. Data pertaining to fruits were obtained from 20 fully ripe fruits per plant. The ripeness index considered full development of the fruit, fruit shape, receptacle depth, and, in some cases, skin color. Seed traits were not considered in the description since they are not important for human consumption. Data were obtained from May 2009 to February 2010. 
Table II.

List of Xoconostle accessions from Mexico, evaluated to study morphological diversity of Opuntia spp.

\begin{tabular}{|c|c|c|c|}
\hline Accession & Species & Mexican origin & Condition \\
\hline Chocho & O. matudae Scheinvar & \multirow{15}{*}{$\begin{array}{l}\text { Saín Alto, } \\
\text { Zacatecas }\end{array}$} & \multirow[t]{15}{*}{ Wild stock } \\
\hline Cuaresmero Blanco Zacatecano & O. matudae Scheinvar & & \\
\hline Apastillado & O. oligacantha Förster & & \\
\hline Blanco Arroyo Hondo & O. matudae Scheinvar & & \\
\hline Cuerón & O. matudae Scheinvar & & \\
\hline Café & O. leucotricha Salm-Dyck $\times$ O. joconostle F.A.C Weber & & \\
\hline Chaveñito & O. sainaltense Scheinvar & & \\
\hline CV-5 & O. reflexispina sp. nov. & & \\
\hline Del Ranchito & O. joconostle F.A.C Weber & & \\
\hline Cambray & O. duranguensis Britton \& Rose & & \\
\hline Cenizo & O. oligacantha Förster & & \\
\hline Guerito & O. oligacantha Förster & & \\
\hline Rojo Sainero & O. matudae Scheinvar & & \\
\hline Rosita & O. matudae Scheinvar & & \\
\hline Sardo & O. galleguiana Scheinvar \& Olalde & & \\
\hline Apan & O. joconostle F.A.C Weber x O. matudae Scheinvar & \multirow{6}{*}{$\begin{array}{c}\text { Villa de Tezontepec, } \\
\text { Hidalgo }\end{array}$} & \multirow{6}{*}{$\begin{array}{c}\text { Community } \\
\text { collection }\end{array}$} \\
\hline De invierno & O. tezontepecana Scheinvar \& Gallegos & & \\
\hline Manso & O. joconostle spp. rubra & & \\
\hline Alimonado & O. joconostle F.A.C Weber & & \\
\hline Del borrego & O. oligacantha Förster & & \\
\hline Matizado & O. leiascheinveriana Martínez \& Gallegos & & \\
\hline
\end{tabular}

To find out the relevant variables for morphological description, a correlation matrix was built, and thereafter a principal component analysis (PCA) [15] was performed considering the complete dataset. The significant variables (14) were subjected to a cluster analysis using the squared Euclidean distance and Ward's minimal variance method [16]. The relationships among the clusters were elucidated by means of a discriminant canonical analysis which included a Mahalanobis distance and a multivariate analysis of variance (MANOVA) [17, 18]. All calculations were done using SAS Version $9.2[19]$.

\section{Results}

Correlation and PCA revealed that only 13 variables were capable of describing the variability of the xoconostle accessions collected for our studies. These variables include: cladode length, number of rows of areoles, number of areoles in the central row, pericarpel length and width, fruit length, fruit diameter, [fruit length / fruit diameter] ratio, areole density in the fruit, fruit receptacle depth, fruit weight, peel weight, and pulp acidity.

The dendrogram generated by the cluster analysis contains three quasi-homogeneous groups consisting of 10, 7 and 4 accessions, respectively (figure 4, table III). The technique allowed clear separation of all individuals and also identified accessions sharing a high percentage of similarity (Rojo Sainero with Sardo; and CV5 with Chaveñito) or potentially redundant accessions.

Two canonical roots (Can) explained $100 \%$ of the variability: Can1 explained $87.55 \%$, and Can2 explained the remaining $12.45 \%$ (table $I V$ ). Can1 was associated with fruit areole density, fruit acidity, number of areola rows and number of areoles in the central row, while Can2 included peel weight, fruit weight and fruit diameter (table V). 


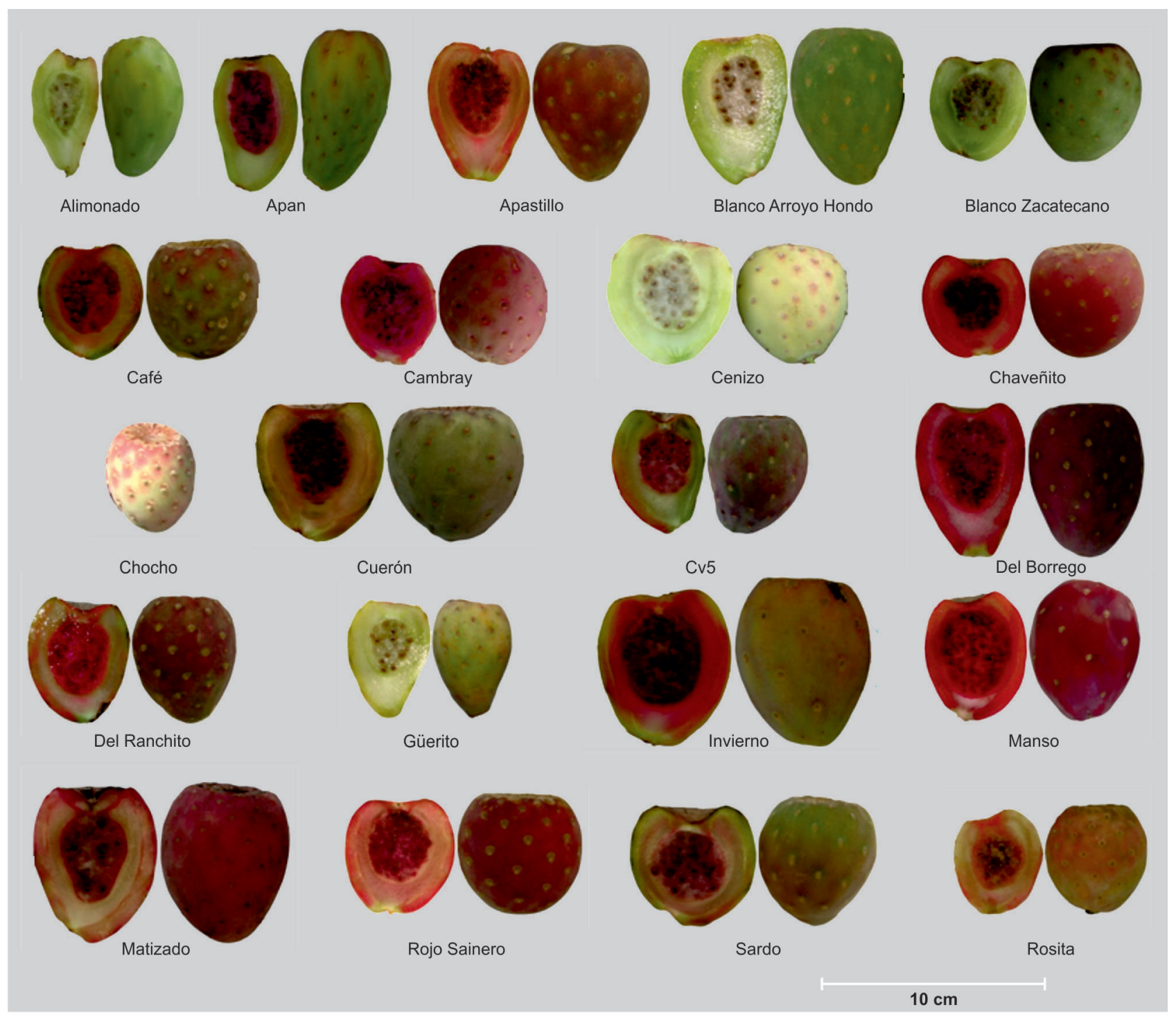

Figure 3.

External and internal features of xoconostles from Central Mexico: despite the wide variability - which is largely unknown - the market is based on fruits similar to Rojo Sainero.
The graphical representation of cluster dispersion (figure 4) shows a clear separation of three groups. However, the Mahalanobis distance indicates that groups 1 and 2 probably belong to a single group (table VI). The multivariate analysis of variance conducted to elucidate similarities among groups (table VII) showed both canonical roots were significantly different. Since the related Tukey test (table VIII) supported that all three groups were significantly different, we considered three groups in this study.

\section{Discussion}

The cluster pattern did not fit the actual botanical classification [3, 6] since all branches contained more than one of the recognized species (table II), a common observation in Opuntia, and in the subfamily Opuntioideae. This is probably related to the high level of phenotypic plasticity, polyploidy and interspecific hybridization [20-22]. Selecting only domesticated accessions with horticultural value reduces the extent of the gene pool and complicates 


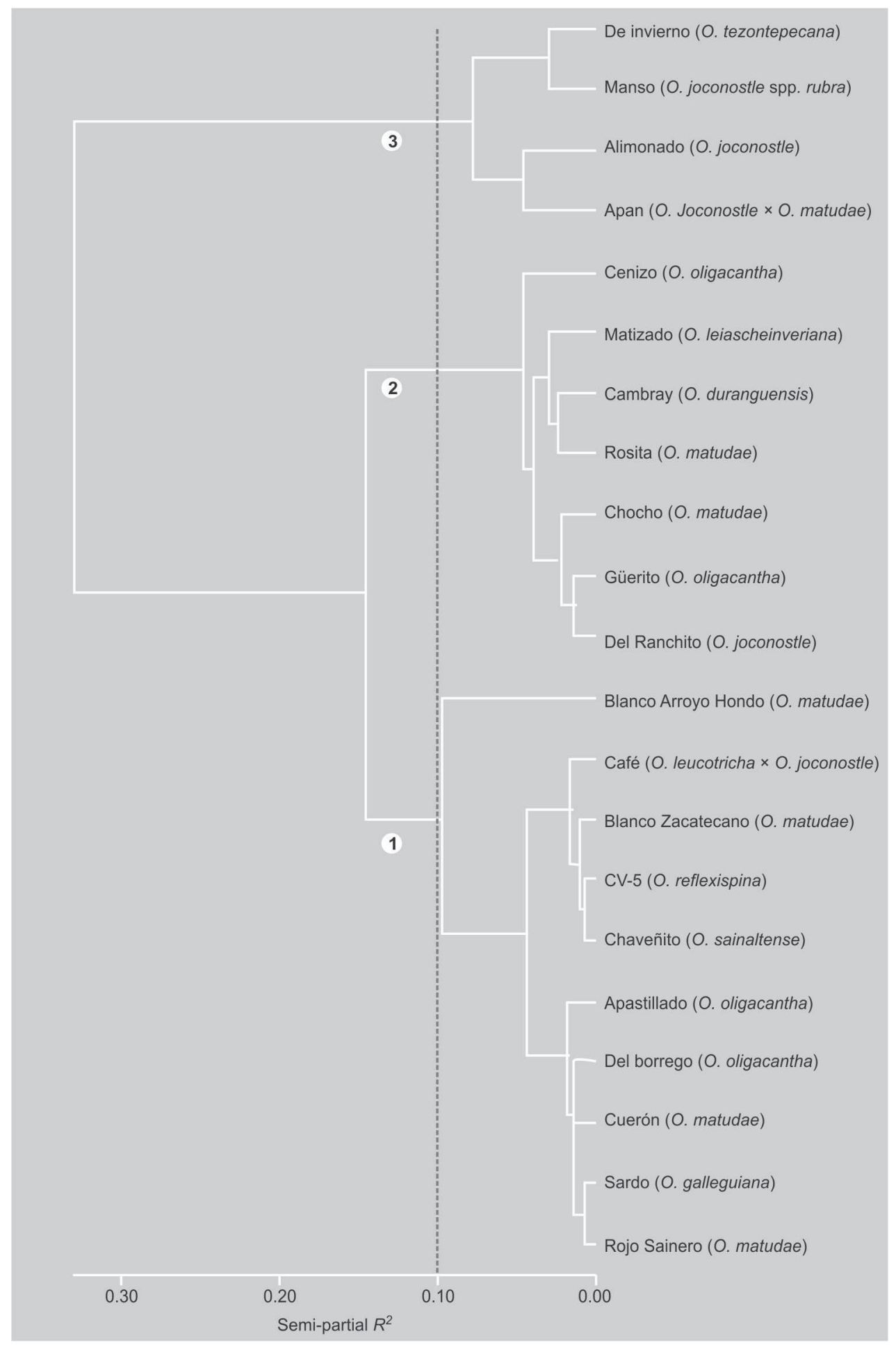

Figure 4.

Dendrogram of 21 accessions of edible xoconostle selections whose human consumption has narrowed the variability, but at the same time will facilitate the breeding process. 


\section{Table III.}

Groups obtained from the cluster analysis carried out for studies on morphological characteristics of different accessions of Opuntia spp. collected in Mexico.

\begin{tabular}{lcc}
\hline Group 1 & Group 2 & Group 3 \\
\hline Apastillado & Cambray & Alimonado \\
Blanco Arroyo Hondo & Cenizo & Apan \\
Blanco Zacatecano & Chocho & de Invierno \\
Café & Güerito & Manso \\
Chaveñito & Matizado & - \\
Cuerón & Ranchito & - \\
CV-5 & Rosita & - \\
Del Borrego & - & - \\
Rojo Sainero & - & - \\
Sardo & - & - \\
\hline
\end{tabular}

the comparisons with taxonomic keys which were usually prepared with a few wild individuals.

Group 1 included ten accessions with large fruits and low areola density. These are typical features of cultivated xoconostles and cactus pears. Acidic fruits are the primary human preference of xoconostles [7]. Groups 1 and 2 included entries from both locations. Group 3 of the dendrogram included mostly accessions from Tezonte- pec (except Matizado and Del Borrego). They are found in both sites, probably due to exchange and dispersion by humans. Xoconostle is still a plant on the path to full domestication since utilization ranges from the practices common for other edible cacti, i.e., selective gathering of particular genotypes, allowing plants with particular traits of interest to remain standing [23], and exploitation in specialized orchards based on plants selected from backyards. Nowadays most of the product obtained is aimed at the commercial market in large urban centers.

Group 3 presented acceptable fruit size, higher areole density and less acidity. Group 2 contained mostly wild accessions with distinctive small fruits and higher areole density than group 1. According to Pimienta-Barrios and Muñoz-Urías, selection of cactus pears and xoconostles has been directed towards large and attractive fruits [24]. In addition, fruit size and areole density were among the significant traits useful to separate wild from domesticated cactus pear in a study conducted by Mondragón-Jacobo [25].

The usual approach in plant germplasm description is to include as many morphological traits as possible. This is a time-consuming and expensive practice, which does not necessarily improve the accuracy of the

\section{Table IV.}

Eigenvalues of the canonical roots obtained from the discriminant canonical analysis carried out on morphological characteristics of different accessions of Opuntia spp. collected in Mexico.

\begin{tabular}{cccccc}
\hline Canonical root & Eigenvalue & Variance extracted & Cumulative variance & Probability ratio & $P$ value \\
\hline 1 & 44.1870 & 0.8755 & 0.8755 & 0.0030 & 0.0024 \\
2 & 6.2830 & 0.1245 & 1.0000 & 0.1373 & 0.0994 \\
\hline
\end{tabular}

\section{Table V.}

Total canonical structure of 21 xoconostle accessions collected in Mexico.

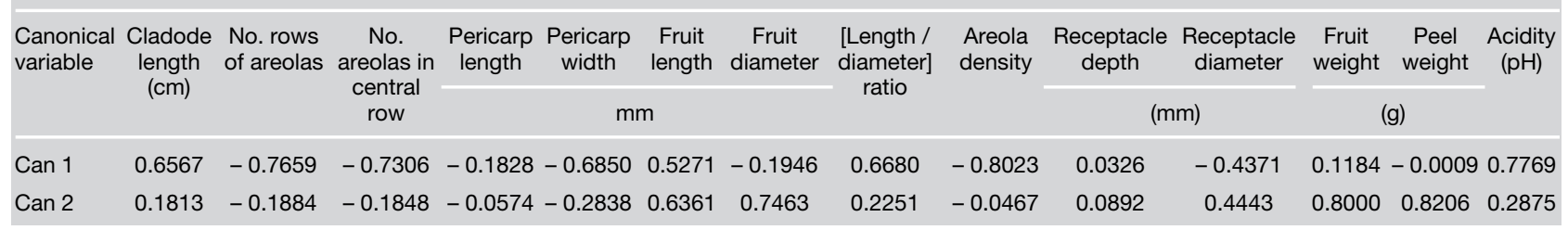




Table VI.
Mahalanobis distance and group
probability for different accessions of
Opuntia spp. collected in Mexico.
$\begin{array}{lccc}\text { Group } & 1 & 2 & 3 \\ 1 & - & 41.3261 \mathrm{~ns} & 277.6114^{\text {** }} \\ 2 & 0.0930 & - & 181.4415^{*} \\ 3 & 0.0033 & 0.0116 & - \\ \text { ns = not significant, }{ }^{*} \text { and }{ }^{* *}=\text { significant at } 5 \% \\ \text { and 1\%, respectively. }\end{array}$

\section{Table VII.}

Summary of multivariate analysis of variance of the groups by cluster analysis carried out on morphological characteristics of different accessions of Opuntia spp. collected in Mexico.

\begin{tabular}{lrcc}
$\begin{array}{l}\text { Canonical } \\
\text { variable }\end{array}$ & $\begin{array}{c}\text { Mean } \\
\text { square }\end{array}$ & $P>\mathrm{F}$ & $R^{2}$ \\
\hline Can 1 & 397.6828 & $<0.0001$ & 0.9779 \\
Can 2 & 56.5468 & $<0.0001$ & 0.8627 \\
\hline
\end{tabular}

descriptions or their usefulness. A similar study conducted by Mondragón-Jacobo for cactus pears found that 20 traits out of 34 traits were relevant to describe the variability of 32 accessions from Central Mexico [25]. Presence of spines and cladode dimensions, length and width, as well as number of areoles on the face of the cladode, allowed the characterization of 46 accessions of cactus pear from north central Mexico. Cladode dimensions as well as fruit size were found to be significant to study a collection of cactus pear from north central Mexico [26]. Some other traits useful in the separation of cactus pear accessions are fruit dimensions and total sugar content [27, 28].

In our study, separation of all accessions was possible with only 13 of $27(51.8 \%)$ variables. Qualitative variables such as flesh and peel color proved useful to distinguish among potentially redundant accessions, as illustrated in the photo chart (figure 3) (Rojo Sainero with Sardo and CV5 with

\section{Table VIII.}

Tukey test of the canonical roots obtained from cluster analysis carried out on morphological characteristics of different accessions of Opuntia spp. collected in Mexico.

\begin{tabular}{lrlrll} 
Group & Can 1 & Can 2 & $n$ \\
\hline 1 & -4.5128 & c & 1.7402 & a & 10 \\
2 & -0.4931 & b & -3.2766 & b & 7 \\
3 & 12.145 & a & 1.3837 & a & 4
\end{tabular}

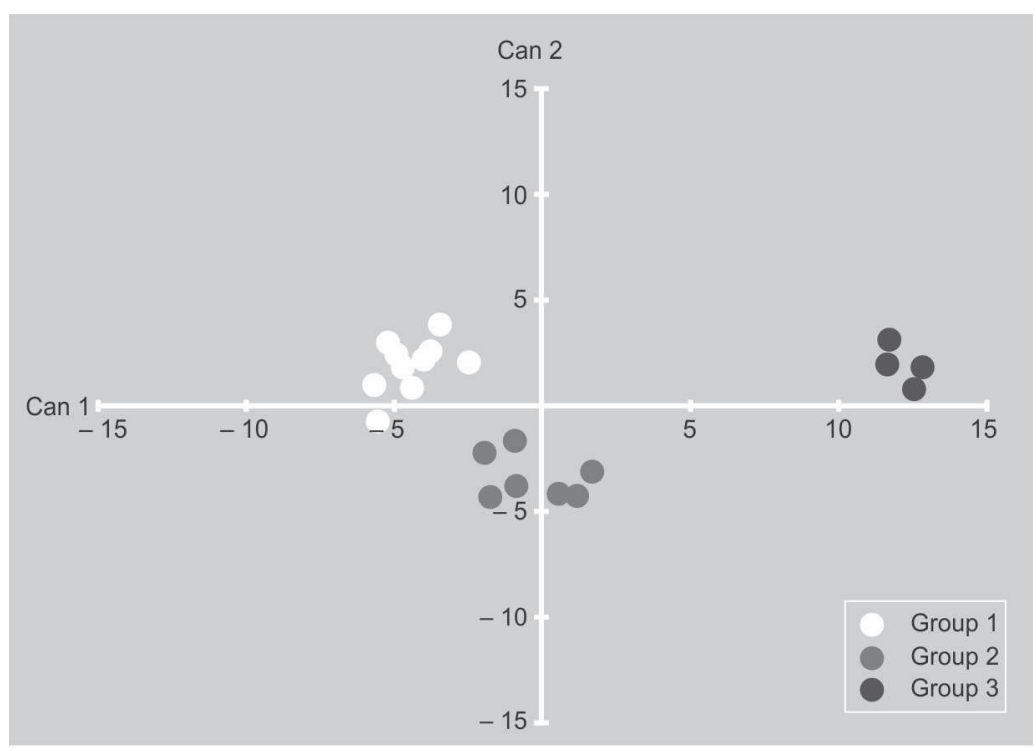

Chaveñito). Both pairs show distinctive colors and hues (Rojo Sainero presents pink pulp and red peel and mesocarp, while Sardo has purple pulp, green/reddish peel and green/pink mesocarp), proving they are separate accessions; it demonstrates the value of graphic catalogs to supplement the quantitative and qualitative data.

Besides fruit acidity, Can1 included traits that are related to plant productivity (fruit areole density, number of areole rows, and number of areoles in the central row), which define the number of areoles in the crown of the cladode. Since the areoles act as buds they will develop into new cladodes and flowers if they are positioned in the aerial

\section{Figure 5.}

Two-dimensional representation of xoconostle group dispersion as determined the first two canonical roots. by cluster analysis based on 
parts, or into roots if they are located underground [29].

On the other hand, Can2 covered traits influencing fruit quality, mainly fruit size, and edible portion. These features suggest domestication of xoconostle followed similar criteria to other fruits: high productivity and fruit quality. However, consumption of fresh xoconostles in Mexico follows the trend of spices and relishes. They are added in small amounts $(<20 \%)$ to regular salsas and stews, and $<10 \%$ to salads. The addition of diced fresh xoconostle to salsas and salty dishes pleasantly modifies the taste and entices further consumption. With a product readily available -and cheaper than regular spices - in semiarid areas of Mexico, it also adds interest to dull diets based on corn and beans. A similar effect can be seen with pungency by adding chilli (Capsicum annum) to dishes, found in most modern cuisines of the world [30]. Recently xoconostles have found a new market niche because they can also be processed as jellies, liquors and caramelized peels using the peel and mesocarp. During preparation the seeds are scooped out before processing. Our study supports that over the centuries the informal selection of this plant by farmers has focused on acidic taste, large fruits and productive plants.

\section{References}

[1] Mondragón-Jacobo C., Gallegos-Vázquez C., Reyes-Agüero J.A., Cactus pear genetic resources the cornerstone of the Mexican cactus pear industry, Acta Hortic. 811 (2009) 39-46.

[2] Olivares-Orozco J.L., Zavaleta-Beckler P., Chimal-Hernández A., Montiel-Salero D., Fierro-Alvarez A., Scheinvar L., Xoconostle: biología y manejo agronómico, Ser. Acad. CBS, no. 45, Dir. Cienc. Biol. Salud, Univ. Autón. Metrop. Unidad Xochimilco, Mex. City, Mex., 2003.

[3] Scheinvar L., Filardo Kerstupp S., Olalde Parra G., Zavaleta Beckler P., Diez especies mexicanas productoras de xoconostles: Opuntia spp. y Cylindropuntia imbricada (Cacteceae), Univ. Nac. Autón. Méx., Univ.
Autón. Estado Hidalgo, Univ. Autón. Metrop., Mex. City, Mex., 2009.

[4] Ávalos-Andrade A., Ramírez-Córdova Y., Goytia-Jiménez M.A., Barrientos-Priego A.F., Saucedo-Veloz C., Etileno en la abscisión del fruto de tres especies del género Opuntia, Rev. Chapingo (Ser. Hortic.) 12 (2006) 117-123.

[5] García-Pedraza L.G., Reyes-Agüero J.A., Aguirre-Rivera J.R., Pinos-Rodríguez J.M., Preliminary nutritional and organoleptic assessment of xoconostle fruit (Opuntia spp.) as a condiment or appetizer, Ital. J. Food Sci. 17 (2005) 333-340.

[6] Reyes-Agüero J.A., Aguirre R.J.R., ValienteBanuet A., Reproductive biology of Opuntia: A review, J. Arid Environ. 64 (2006) 549-585.

[7] Scheinvar L., Cactaceae, In: Rzedowski J., Calderón de Rzedowski G. (comp. y eds.), La Flora de México, Cent. Reg. Bajío, Inst. Ecol., Esc. Nac. Cienc. Biol., Inst. Politéc. Nac., Mex. City, Mex., 2001, pp. 431-470.

[8] Guzmán-Maldonado S.H., Morales-Montelongo A.L., Mondragón-Jacobo C., HerreraHernández M.G., Guevara-Lara F., ReynosoCamacho R., Physicochemical, nutritional and functional characterization of fruits xoconostle (Opuntia matudae) pears from central-Mexico region, J. Food Sci. 75 (2010) 485-491.

[9] Proteggente A.L., Pannala A.S.D., Paganga G., Uren L.V., Wagner E., Wiseman S., De Put F.V., Dacombe C., Rice-Evans C.A., The antioxidant activity of regularly consumed fruit and vegetables reflects their phenolic and vitamin C composition, Free Radic. Res. 36 (2002) 217-233.

[10] Pimienta-Barrios E., Méndez-Morán L., Ramírez-Hernández B.C., García de AlbaGarcía J.E., Domínguez-Arias R.M., Efecto de la ingestión del fruto de xoconostle (Opuntia joconostle Web.) sobre la glucosa y lípidos séricos, Agrociencia 42 (2008) 645653.

[11] Gallegos Vázquez C., Cervantes-Herrera J., Méndez-Gallegos S. de J., La producción de tuna en la región centro norte de México, Geogr. Agríc. 33 (2004) 143-157.

[12] Sánchez-Venegas G., Ortega-Delgado M.L., Componentes químicos durante la maduración del fruto de Opuntia joconostle Weber forma cuaresmero, Agrociencia 30 (1996) 541-548. 
[13] Gallegos-Vázquez C., Barrientos-Priego A.F., Reyes-Agüero J.A., Núñez-Colín C.A., Mondragón-Jacobo C., Clusters of commercial cultivars of cactus pear and xoconostle using UPOV traits, J. Prof. Assoc. Cactus Dev. 13 (2011) 10-23.

[14] Anon., Cactus pear and xoconostles (Opuntia, Groups 1 \& 2), Guidelines to conduct tests for distinctness, uniformity and stability, TG/217/1, Int. Union Prot. New Var. Plants, UPOV, Geneva, Switz., 2004.

[15] González-Andrés F., Caracterización morfológica, in: González-Andrés F., Pita Villamil J.M. (Eds.), Conservación y caracterización de recursos filogenéticos, Publ. Inst. Nac. Educ. Agríc., Valladolid, Esp., 2001, pp. 199217.

[16] Ward J.H. Jr., Hierarchical grouping to optimize an objective function, J. Am. Stat. Assoc. 58 (1963) 236-244.

[17] Johnson D.E., Métodos multivariados aplicados al análisis de datos, Int. Thompson Ed., Mex. City, Méx., 1998.

[18] Núñez-Colín C.A., Nieto-Ángel R., BarrientosPriego A.F., Sahagún-Castellanos J., Segura S., González-Andrés F., Variability of three regional sources of germplasm of Tejocote (Crataegus spp.) from central and southern Mexico, Genet. Resour. Crop Evol. 55 (2008) 1159-1165.

[19] Anon., SAS/STAT software version 9.2: The power to know, SAS Inst., Cary, U.S.A., 2009.

[20] Wallace R.S., Gibson A.C., Evolution and systematic, in: Nobel P.S. (Ed.), Cacti: biology and uses, Univ. Calif. Press, Berkeley, U.S.A., 2002, pp. 1-22.

[21] Caruso M.S., Curro S., Las Casas G., La Malfa S., Gentile A., Microsatellite markers help assess genetic diversity among Opuntia ficus-indica cultivated genotypes and their relation with related species, Plant Syst. Evol. 90 (2010) 85-97.
[22] Scheinvar L., Taxonomía de las Opuntias utilizadas, in: Barbera G., Inglese P., PimientaBarrios E. (Eds.), Agroecologia, cultivo y usos del nopal, Estud. FAO, Ser. Prod. Prot. Veg. 132, Rome, Italy, 1999, pp. 21-28.

[23] Casas A., Otero-Arnaiz A., Perez-Negron E., Valiente-Banuet A., In situ management and domestication of plants in Mesoamerica, Ann. Bot. 100 (5) (2007) 1101-1115.

[24] Pimienta-Barrios E., Muñoz-Urías A., Domesticación de nopales tuneros (Opuntia spp.) y descripción de las principales variedades cultivadas, in: Barbera G., Inglese P., Pimienta-Barrios E. (Eds.), Agroecologia, cultivo y usos del nopal, Estud. FAO, Ser. Prod. Prot. Veg. 132, Rome, Italy, 1999, pp. 61-67.

[25] Mondragón-Jacobo C., Caracterización genética de una colección de nopal (Opuntia $\mathrm{spp})$ de la región centro de México, Agric. Téc. Méx. 28 (2002) 3-14.

[26] Peña-Valdivia A., Luna-Cavazos M., CarranzaSabas J.A., Reyes-Agüero J.A., Flores A., Morphological characterization of Opuntia: a multivariate analysis, J. Prof. Assoc. Cactus Dev. 2008 (1) 1-21.

[27] Valdes-Zepeda R.D, Blanco-Macias F., Gallegos-Vazquez C., Ordenacion y clasificación numérica en nopal tunero mediante atributos de fruto, Rev. Chapingo (Ser. Hortic.) 9 (2) (2003) 81-95.

[28] Gutierrez-Acosta F., Valdes-Cepeda R.D. Blanco-Macias F., Multivariate analysis of cactus pear (Opuntia spp.) fruits germplasm collection, Acta Hortic. 581 (2002) 111-118.

[29] Pimienta-Barrios E., El nopal tunero, Colecc. Tiempos Cienc., Univ. Guadalaj., Guadalaj., Mex., 1990, pp. 246.

[30] Bosland P.W., Capsicums: Innovative uses of an ancient crop, in: Janick J. (Ed.), Progress in new crops, ASHS Press, Arlingt., U.S.A., 1996, pp. 479-487. 


\section{Diversidad morfológica de xoconostles (Opuntia spp.) o tunas ácidas: una contribución mexicana a los alimentos funcionales.}

Resumen - Introducción. Los xoconostles o tunas ácidas (Opuntia spp.) son frutas apreciadas por su mesocarpio carnoso y ácido, son morfológicamente diferente de las tunas que son dulces, jugosas y con semillas; ambas crecen en el altiplano semiárido del centro de México, toleran suelos pobres y lluvias escasas, desarrollado como cultivo formal durante las últimas cinco décadas. Los xoconostles silvestres son abundantes en las regiones semiáridas de México; genotipos domesticados están presentes en traspatios y huertos comerciales. Los atributos del Xoconostle son efecto antihipoglucémico, reducción del colesterol alto y de la obesidad. Su cáscara es rica en fibra, minerales, fenoles y betalainas solubles; presenta mayor capacidad antioxidante que fresa, frambuesa, ciruela roja, uva, pera y manzana. El presente estudió describe los principales cultivares de xoconostle con valor hortícola y contribuye a la clarificación de sus relaciones morfológicas. Materiales y métodos. Veintiuna accesiones de Villa Tezontepec, Hidalgo y Saín Alto, Zacatecas, México fueron descritas usando 27 variables de cladodio, flores y frutos; las variables significativas fueron seleccionadas mediante correlación y ACP, después se hicieron un análisis clúster y un análisis discriminante canónico. Resultados. Trece variables fueron significativas para discriminar las accesiones: longitud de cladodio, número de filas de areolas, número de areolas en la hilera central, longitud y anchura del pericarpio, longitud, diámetro, relación largo/ancho, densidad de areolas y peso del fruto, profundidad del receptáculo, peso de la cáscara y acidez de la pulpa. Dos raíces canónicas (Can) explicaron la variabilidad; El Can1 (densidad de areolas del fruto, acidez, número de filas de areolas y número de areolas en la fila central) explicó el $87.55 \%$ y el Can2 (peso de cáscara y el diámetro y peso del fruto) el restante $12.45 \%$. Discusión. Can1 fue relacionado a la productividad de la planta, mientras que Can2 comprende principalmente características de calidad de fruta; ambas de interés primordial para la utilización humana probablemente siguiendo un patrón de domesticación. Los grupos no correspondieron a la clasificación taxonómica actual.

México / Opuntia / recursos genéticos / biodiversidad / alimentación humana 